\title{
TRANSIT PARTTKEL DAN CAIRAN DALAM SALURAN PENCERNAAN SAPI PERAH PRODUKSI TINGGI YANG MENDAPAT RANSUM DENGAN ARAS KONSENTRAT BERBEDA
}

\section{INTISARI}

\section{Budi Prasetyo Widyobroto ${ }^{1}$}

Lama tinggal pakan di dalam total saluran pencernaan meningkat dengan meningkatnya aras konsentrat dalam ransum, meskipun penyebabnya masih belum jelas antara pengaruh kenaikan konsentrat atau kenaikan kandungan pati. Penelitian bertujuan untuk mengetahui pengaruh aras konsentrat dalam ransum terhadap transit partikel dan dinamik cairan dalam saluran pencernaan sapi perah produksi tinggi. Tiga aras konsentrat yaitu rendah (R) $20 \%$, sedang (S) $35 \%$ dan tinggi (T) $50 \%$ dengan kandungan serat $38 \%$ dan pati $31 \%$ dan silase jagung diberikan ad libitum digunakan dalam penelitian ini. Enam ekor sapi FH, berat badan $\pm 550-600 \mathrm{~kg}$, produksi susu $\pm 32 \mathrm{~kg} / \mathrm{hari}$ dan difistulasi pada bagian rumen dan canulasi duodenum menggunakan kerangka Latin Square $(3 \times 3)$, masing-masing 2 replikasi. Estimasi lama tinggal pakan di total saluran pencernaan (TMRT), lama tinggal di rumen (TK1), lama tinggal di cecum-colon proksimal dan waktu pengecilan ukaran partikel (TK2) dari silase jagung, konsentrat dan cairan dihitung dengan teknik marka simpel berdasarkan ekskresi marka fase padat (Europium dan Ytterbium) dalam feses.dan marka cair (CrEDTA) dihitung berdasarkan penurunan konsentrasi marka dalam cairan rumen setelah introduksi dengan dosis tunggal. Data dianalisis variansi dan dilanjutkan uji DMRT. Hasil penelitian menunjukkan bahwa TMRT dan TK1 silase jagung berbeda tidak nyata antar perlakuan, masingmasing 50,$8 ; 52,0 ; 51,2$ jam dan 26,$8 ; 27,7$ dan 27,0 jam untuk $\mathbf{R}$, $\mathbf{S}$ dan T. TMRT dan TK1 konsentrat berbeda tidak nyata antar perlakuan, masing-masing 39,$0 ; 37,4 ; 36,7$ jam dan 21,6 ; 20,$8 ; 19,9$ jam untuk $R, S$ dan T. TMRT dan TK1 silase jagung lebih lama $(P<0,01)$ dibanding konsentrat, perbedaannya masing-masing 13,7 jam 6,4 jam. TMRT ransum total lebih tinggi $(\mathrm{P}<0,05)$ pada $\mathrm{R}$ dibanding $\mathrm{T}(48,4$ vs 43,9 jam). Dinamik cairan rumen berbeda tidak nyata antar perlakuan. Kesimpulan, TMRT dan TK1 ransum menurun pada aras konsentrat $50 \%$, tetapi tidak mempengaruhi secara nyata dinamik cairan rumen.

(Kata Kunci: Sapi Perah, Aras Konsentrat, Transit Partikel, Dinamik Cairan).

Buletin Peternakan 22 (4): 168 - 178, 1998

\footnotetext{
${ }^{1}$ Fakultas Peternakan Universitas Gadjah Mada, Yogyakarta 55281.
} 


\title{
PASSAGE RATE OF PARTICLES AND LIQUID IN THE DIGESTIVE TRACT OF HIGH YIELDING DAIRY COWS FED DIFFERENT LEVEL OF CONCENTRATES
}

\begin{abstract}
The total mean retention time (TMRT) of feed particles increases with the amount of cereal based concentrate in the diet. However, there is confusion between this effect and an increase of starch content. The objectives of this study were to determine the effect of the level of concentrate on passage rate of particles and liquid in the digestive tract of high yielding dairy cows. Three diets with different level of concentrate namely $20 \%$ (R), $30 \%$ (S) and $50 \%$ (T), with the same starch (31\%) and NDF content (38\%) were studied in a two latin square design using 6 adult rumen fistulated cows weighing about $550-600 \mathrm{~kg}$ and milk production about $32 \mathrm{~kg} /$ day. The 3 diets were fed ad libitum and consisted of maize silage as basal diet and concentrate. The ruminal outflow rate of liquide (KI) was estimated by Poly Ethilene Glycol (PEG) dilution. The rate of passage of Europium-labelled maize silage and Dysprosium-labeled concentrate were measured simultaneously. TMRT of maize silage and concentrate in the digestive tract were calculated from the quantities of Eu and Dy excreted at each interval of collection. Results on particle transit showed that TMRT and TK1 of maize silage were not significantly difference between $R, S$ and T being $50.8 ; 52.0 ; 51.2 \mathrm{~h}$ and $26.8 ; 27.7 ; 27.0 \mathrm{~h}$, respectively. TMRT and TK1 of concentrate were not significant difference between $\mathrm{R}, \mathrm{S}$ and $\mathrm{T}$ being $39.0 ; 37.4 ; 36.7 \mathrm{~h}$ and $21.6 ; 20.8 ; 19.9 \mathrm{~h}$, respectively. TMRT and TK1 maize silage were higher $(\mathrm{P}<0.01)$ than that of concentrate, the difference were $13.7 \mathrm{~h}$ and $6.4 \mathrm{~h}$, respectively. TMRT of total diet of $\mathrm{R}$ was higher $(\mathrm{P}<0.05)$ than that of T (48.4 vs 43.9 h). Dynamic of rumen liquor were not significant difference between $R, S$ and T. Conclusion, TMRT and TK1 of total diet decreased with the level of concentrate (50\%) in the diet, but the dynamic of rumen liquor were not affected.
\end{abstract}

(Key Words: Dairy Cows, Concentrate Level, Particle Transit, Liquid Dynamic).

Pendahuiuan

Karakteristik fisik kecernaan yaitu transit partikel pakan dan dinamik cairan di saluran pencernaan belum banyak mendapat perhatian, walaupun fenomena tesebut juga penting dalam proses pencernaan. Lama tinggal pakan dalam rumen menggambarkan lama kontak pakan dengan ensim mikrobia rumen (Mambrini, 1991), mempengaruhi hasil akhir fermentasi dan sintesis protein mikrobia serta kecepatan dan kemampuan mengkonsumsi pakan (Harisson et al., 1975 ; Faverdin et al., 1995).

Isi rumen bersifat heterogen dan terstratifikasi dengan jelas menjadi gas, cairan, partikel kecil dan partikel besar, dan kondisi tersebut dapat dipertahankan karena adanya motilitas retikulo-rumen (Reid, 1986). Martz dan Belyea (1986) ; Hooper dan Welch (1985) melaporkan bahwa ukuran partikel yang proporsinya terbesar adalah berukuran 50-1200 $\mu \mathrm{m}$ dengan densitas 0,9-1,2. Partikel kecil yang berada di kantong ventral mempunyai probabilitas keluar rumen paling besar (Ellis et al., 1988), selanjutnya Katho et al. (1988) menekankan pentingnya densitas partikel pada mekanisme pergantian partikel pakan keluar rumen. Bentuk partikel pakan juga berpengaruh pada pergantian partikel dalam rumen, partikel ukuran $0,5 \mathrm{~cm}$ lebih cepat melewati rumen bila dalam bentuk panjang dibanding bentuk bulat. Cairan dalam rumen menempati $85 \%$ biomass rumen, dapat berupa 
cairan bebas atau berasosiasi dengan partikel kecil, cairan tersebut berasal dari saliva (70$90 \%$ ), air pakan (10-30\%) dan sisanya air minum serta pertukaran air dalam dinding rumen (Zorilla-Rillos et al., (1990).

Berdasarkan data yang telah dipublikasikan menunjukkan bahwa aras konsentrat dalam ransum tidak berpengaruh secara nyata pada lama tinggal pakan dalam saluran pencernaan bila aras konsentrat $<70 \%$ (Weiss et al., 1989; Ceceva et al., 1990; Klusmeyer et al., 1991). Aras konsentrat dalam ransum > $70 \%$ menyebabkan lama tinggal residu pakan dalam saluran pencernaan meningkat, terutama pada ternak dengan pakan terbatas (Goetsch dan Owen 1985; Colucci et al., 1990). Pengaruh negatif kenaikan aras konsentrat dalam ransum disebabkan oleh modifikasi struktur isi rumen, penurunan $\mathrm{pH}$, motrisitas dan pemurunan produksi saliva (Poncet, 1991).

Colucci et al. (1982) melaporkan bahwa kenaikan aras konsentrat dari $18 \%$ menjadi $67 \%$ meningkatkan lama tinggal pakan di total saluran pencernaan dari 24-44 jam pada sapi perah kering dengan pakan terbatas, sedangkan pada sapi perah berproduksi dengan pakan ad libitum peningkatannya hanya 4 jam. Gasa et al. (1991) menekankan bahwa lama tinggal pakan dalam saluran pencernaan sangat dipengaruhi konsumsi bahan kering. Lama tinggal pakan hijauan dalam rumen dan total saluran pencernaan lebih lama dibanding pakan konsentrat (Colucci et al., 1989), lama tinggal partikel hijauan dalam rumen bervariasi antara 15 - 35 jam.

Pergantian cairan dalam rumen tidak berbeda nyata sampai aras konsentrat dalam ransum $<70 \%$, tetapi pada aras konsentrat $>$ $70 \%$ pergantian cairan dalam rumen menurun secara nyata (Goetsch dan Owens, 1985; Rode dan Satter, 1988). Selanjutnya Colucci et al. (1989), Weiss et al. (1989), Ceceva et al. (1990) dan Klusmeyer et al. (1991) juga melaporkan bahwa pergantian cairan dalam rumen tidak berbeda nyata atau hanya cenderung berbeda bila aras konsentrat dalam ransum tidak melebihi $65 \%$. Sedangkan Gasa et al. (1991) melaporkan penurunan pergantian cairan dalam rumen sebesar $2,2 \%$ /jam dengan peningkatan aras konsentrat dari $24 \%$ menjadi $57 \%$.

Berdasarkan latar belakang diatas penelitian ini dilakukan untuk mengetahui pengaruh aras konsentrat dengan imbangan pati dan serat tidak berbeda terhadap transit partikel pakan dan dinamik cairan dalam rumen pada sapi perah produksi tinggi.

\section{Ternak}

\section{Materi dan Metode}

Penelitian ini dilakukan di Station de Recherches sur la Vache Laitiere, INRA Saint Gilles, France, menggunakan enam sapi perah produksi tinggi sedang laktasi, berat badan sapi $\pm 635 \mathrm{~kg}$ dan produksi susu $4 \% \pm 32 \mathrm{~kg} / \mathrm{hari}$ yang difistulasi pada bagian rumen dan dikamulasi duodenum. Sapi diletakkan dalam kandang individu dan sebelum penelitian dimulai sapi-sapi diberi obat anti cacing.

\section{Pakan}

Tiga aras konsentrat dalam ransum basal silase jagung di uji dalam penelitian ini, yaitu $20 \%$ (rendah) $=\mathbf{R}(20 \%), 35 \%$ (sedang) $=\mathrm{S}(35 \%)$ dan $50 \%$ (tinggi) $=\mathrm{T}(50 \%)$ menurut kerangka Latin Square $3 \times 3$, masingmasing 2 replikasi. Konsentrat diberikan sesuai dengan kebutuhan hidup pokok dan produksi susu (Coulon et al., 1989). Ransum basal berupa silase jagung dan air minum diberikan secara ad hibinum, ransum diberikan dua kali sehari (pukul 08.00 dan 16.00). Komposisi kimia bahan pakan yang digunakan tertera pada Tabel 1., sumber undegraded protein yang digunakan adalah bungkil kedelai formaldehide dan sumber $\mathrm{N}$ terdegradasi digunakan urea. Komposisi dan kandungan gizi ransum tercantum pada tabel 2. Ransum yang diberikan iso energi dan iso protein $(1,6$ $\mathrm{Mcal} / \mathrm{kg}$, 16,4\%). Kandungan pati : neutral detergent fiber (NDF) pada ketiga ransum masing-

$; 27,7:$

Komp

Bahan

Proteir

Lemak

Pati

NDF

ADF

ADL

1) : 25 , me kal:

2) : Bun rum

Penguku cairan

periode), adaptasi

Selama pe dan samp sampelnya bahan org acid der Pengukura konsentrat masing din biji jagu Dysprosiur Mambrini termarka 8.00 (sebe yang tida dimasukka dalam saliv feses untul $11,13,16$, $83,83,96$, 
masing-masing adalah $31,2: 40,3 ; 29,5: 39,2$ $; 27,7: 39,2$. setelah introduksi marka. Pergantian cairan dalam rumen selama 24 jam diestimasi dengan perubahan konsentrasi marka Poly Ethilene

Tabel 1. Komposisi kimia bahan pakan

\begin{tabular}{lcccc}
\hline & \multicolumn{4}{c}{ Bahan pakan } \\
\hline & Silase jagung & Konsentrat $^{1}$ & By pass protein $^{2)}$ & Urea \\
\hline Komposisi kimia (\% BK) & & & & \\
Bahan organik & 96,0 & 91,6 & 92,6 & - \\
Protein kasar & 8,6 & 13,9 & 48,1 & 287,5 \\
Lemak & 2,8 & 3,3 & 2,5 & - \\
Pati & 35,9 & 22,5 & 6,2 & - \\
NDF & 43,5 & 38,1 & 21,7 & - \\
ADF & 20,5 & 17,1 & 10,7 & - \\
ADL & 3,1 & 2,1 & 2,6 & -
\end{tabular}

1) : $25,0 \%$ Bekatul gandum, 30,0\% pulp betterave, $25,0 \%$ gandum, $10,0 \%$ alfalfa hay, $5,0 \%$ melases, $1,0 \%$ lemak hewani, $1,5 \%$ sodium dikarbonat, $1,0 \%$ kalsium fosfat, $0,5 \mathrm{Nacl}, 1,0 \%$ kalsium karbonat.

2) : Bungkil kedelai yang dilindungi dengan tanin untuk menghindari degradasi mikroba di dalam rumen.

Pengukuran transit partikel dan dinamik cairan

Penelitian dilakukan selama 3 bulan ( 3 periode), setiap periode terdiri dari periode adaptasi 15 hari dan periode koleksi 15 hari. Selama penelitian sampel pakan yang diberikan dan sampel sisa pakan diukur dan diambil sampelnya untuk analisis bahan kering (BK), bahan organik (BO), protein kasar (PK), NDF, acid detergent fiber (ADF) dan pati. Pengukuran lama tinggal silase jagung dan konsentrat di saluran pencernaan masingmasing dimarka Europium (Eu) setelah diambil biji jagungnya dan konsentrat dengan Dysprosium (Dy) sesuai dengan prosedur Mambrini (1991). Silase dan konsentrat termarka didistribusikan pada ternak pukul 8.00 (sebelum distribusi pakan pagi) dan sisa yang tidak dikonsumsi setelah 30 menit dimasukkan dalam rumen setelah dimasukkan dalam saliva buatan pada suhu $38^{\circ} \mathrm{C}$. Sampel feses untuk analisis marka diambil pada 7,9 , $11,13,16,19,23,27,32,38,47,55,63,72$, $83,83,96,120,144,168,192$ dan 216 jam
Glycol (PEG) setelah introduksi sebanyak 25g/kg BK yang dikonsumsi (Mambrini, 1991). Introduksi PEG dilaksanakan pada jam 7.00 dan cairan rumen di ambil pada hari pertama (pukul 10.00, 10.30 dan 11.00) dan hari kedua pada jam yang sama. Kinetik ekskresi Eu dan $\mathrm{Yb}$ digunakan untuk analisis lama tinggal pakan di kompartimen saluran pencernaan yang meliputi lama tinggal partikel pakan di dalam total saluran pencernaan (TMRT), lama tinggal partikel pakan dalam retikulo-rumen (TK1) dan waktu komunisi partikel serta lama tinggal pakan di cecum-colon proksimal dan distal (TK2) menurut Uden (1984). TMRT, TK1, TK2 dan kp ransum dihitung berdasarkan penjumlahan konsumsi hijauan dan konsentrat riil. Penurunan konsentrasi PEG cairan rumen setelah introduksi dosis tunggal digunakan untuk mengestimasikan pergantian cairan dalam rumen (K1), volume rumen (V) dan flux cairan keluar numen (F1) menunut Mambrini (1991). 
Tabel 2. Proporsi, komposisi kimia dan nilai nutrisi ransum

\begin{tabular}{|c|c|c|c|}
\hline & $20(\mathrm{R})$ & $40(S)$ & $60(\mathrm{I})$ \\
\hline \multicolumn{4}{|l|}{ Proporai raneum (\% BK) } \\
\hline Silase jagung & 78,0 & 63,1 & 48,2 \\
\hline Konsentrat percobaan & 10,0 & 27,0 & 43,0 \\
\hline By pass protein & 10,0 & 8,0 & 7,0 \\
\hline Mineral-vitamin ${ }^{3}$ ) & 0,8 & 0,8 & 0,8 \\
\hline Urea & 1,2 & 1,1 & 1,0 \\
\hline \multicolumn{4}{|c|}{ Komposisi lkimia ransum (\% BK) } \\
\hline Bahan organik & 94,3 & 93,6 & 92,9 \\
\hline Protein kasar & 16,4 & 16,3 & 16,4 \\
\hline Lemak & 2,8 & 2,9 & 3,0 \\
\hline Pati & 31,2 & 29,5 & 27,7 \\
\hline NDF & 40,3 & 39,9 & 39,2 \\
\hline $\mathrm{ADF}$ & 19,0 & 18,6 & 18,1 \\
\hline $\mathrm{ADL}$ & 2,9 & 2,8 & 2,6 \\
\hline \multicolumn{4}{|l|}{ Nilai nutrisi ransum } \\
\hline EN laktasi (Mcal/kg BK) & 1,6 & 1,6 & 1,6 \\
\hline PDI $(g / \mathbf{k g} \text { BK })^{4)}$ & 102,0 & 98,0 & 97,0 \\
\hline
\end{tabular}

1) : $25,0 \%$ Belatul gandum, 30,0\% pulp betterave, $25,0 \%$ gandum, 10,0\% alfalfa hay, $5,0 \%$ melases, $1,0 \%$ lemak hewani, $1,5 \%$ sodium dikarbonat, $1,0 \%$ kalsium fosfat, 0,5 Nacl, $1,0 \%$ kalsium karbonat.

2) : Bungkil kedelai yang dilindungi dengan tanin untuk menghindari degradasi mikroba di dalam rumen.

3) : $7 \%$ phospor, $22 \%$ calcium, 3\% sodium, 190 ppm S, $1060 \mathrm{ppm} \mathrm{Cu,} 5800 \mathrm{ppm} \mathrm{Zn,} 3800$ ppm $\mathrm{Mn}, 252000 \mathrm{IU} / \mathrm{kg}$ Vit A, $50400 \mathrm{IU} / \mathrm{kg}$ Vit D3, 32 ppm Vit E.

4) PDI : Protein Digestible in the Intestine

\section{Analisis kimia}

Kandungan BK, BO, PK dan lemak dianalisis menurut petunjuk (AOAC, 1980), kandungan NDF dan ADF menurut Van Soest (1963) dan kandungan pati menurut AFNOR (1990). Kandungan $\mathrm{Eu}$ dan $\mathrm{Yb}$ dianalisis menurut Mambrini (1991) dan PEG menurut Malawer dan Powell (1967).

\section{Analisis statistik}

Data konsumsi NDF, pati, TMRT, TK1, TK2, TT, K1, V dan Flux dianalisis variansi merurut skema percobaan Latin Square $3 \times 3$, masing-masing 2 ulangan dengan program General Linear Model, SAS (1987) dan bila terdapat perbedaan nyata antar perlakuan dilanjutkan dengan uji DMRT (Duncan's Multiple Range Test).
Elcskre:

tertera dalam fe dibandin konsentr distribusi tercapai terdeteks inkubasi, introduks diekskres walaupur masih dia Eu dan Y untuk st Hasil di dilaporka: mempuny dan rekup 


\section{Hasil dan Penebahasan}

\section{Ekskereei marika}

Kurve eksresi Eu dan $\mathrm{Yb}$ dalam feces tertera pada Gambar 1. Munculnya marka dalam feces lebih dulu pada konsentrat $(\mathrm{Yb})$ dibanding silase jagung (Eu). Puncak konsentrasi $\mathrm{Yb}$ dicapai pada 25 jam setelah distribusi marka, sedangkan $\mathrm{Eu}$ puncak tercapai pada 46 jam. Marka $\mathrm{Yb}$ mulai tidak terdeteksi (nol) pada \pm 175 jam setelah inkubasi, sedangkan Eu pada \pm 175 jam setelah introduksi. Konsentrasi marka yang diekskresikan lebih tinggi $\mathrm{Yb}$ dibanding $\mathrm{Eu}$, walaupun total ekskresi marka kedua-duanya masih diatas $90 \%$. Hal ini menunjukkan bahwa Eu dan $\mathrm{Yb}$ merupakan marka yang relatif baik untuk studi transit pada ternak ruminansia. Hasil diatas sesuai dengan hasil yang dilaporkan Mambrini (1991) bahwa Yb dan Eu mempunyai affinitas yang baik sebagai marka dan rekuperasi marka dalam feces $>85 \%$.

\section{Transit silase jagung}

Lama tinggal silase jagung di total saluran pencernsan (TMRT) berbeda tidak nyata antar perlakuan, masing-masing 50,8 ; 52,0 dan 51,2 jam (Tabel 3.) Hal ini didukung lama tinggal silase jagung di dalam rumen (TK1) berbeda tidak nyata antar ketiga perlakuan, masing-masing 26,$8 ; 27,7$ dan 27,0 jam untuk $R, S$ dan $T$. Selain itu waktu yang dibutuhkan untuk memperkecil partikel besar menjadi partikel kecil (TK2) antara ketiga perlakuan juga berbeda tidak nyata. Nilai Tk1 berhubungan dengan pergantian partikel keluar rumen (kp) sebesar 3,73 ; 3,61 dan 3,70\%/jam untuk $\mathrm{R}, \mathrm{S}$ dan T. Perbedaan aras konsentrat dalam ransum tidak memberikan perbedaan TMRT, TK1 dan kp disebabkan konsentrat yang digunakan mempunyai kandungan serat (NDF) relatif tinggi dan kualitas hijauan yang digunakan baik, sehingga intake NDF dan pati tidak berbeda antara perlakuan (masing-masing 8,$1 ; 8,6 ; 8,8 \mathrm{~kg} / \mathrm{ekor} / \mathrm{hari}$ dan 6,$6 ; 6,5$ dan 6,6

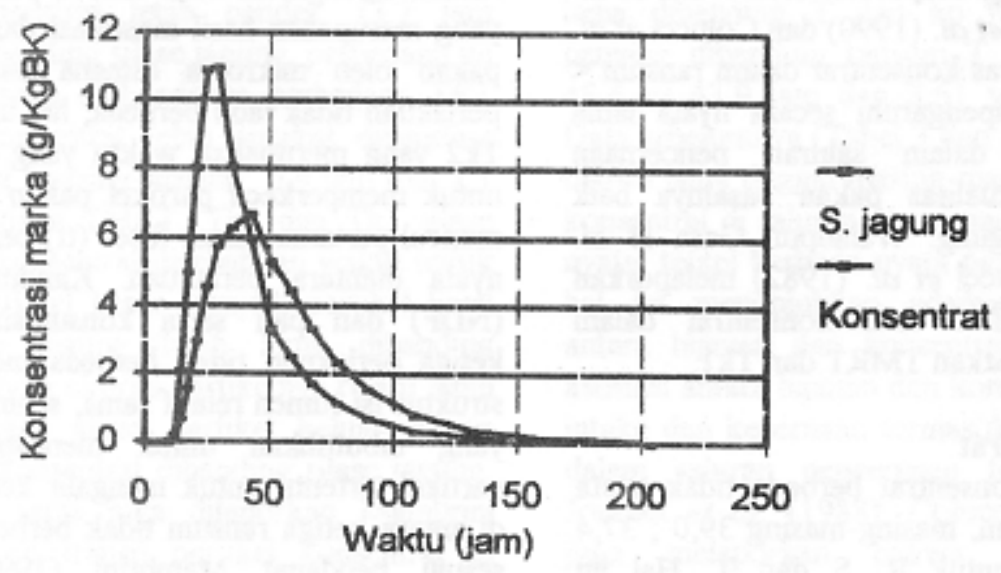

Gambar 1. Kurve ekskresi Europium dan Ytterbium dalam feces 
Tabel 3. Pengaruh aras konsentrat terhadap konsumsi bahan kering, NDF dan pati serta transit silase jagung dalam saluran pencernaan

\begin{tabular}{|c|c|c|c|c|c|}
\hline Item & $20(\mathrm{~T})$ & $35(\mathrm{~S})$ & $50(\mathrm{~T})$ & $\mathrm{SE}$ & $\begin{array}{l}\text { Analisis } \\
\text { statistik }\end{array}$ \\
\hline \multicolumn{6}{|l|}{ Konsamani } \\
\hline NDF (kg/ekor/hari) & 8,1 & 8,6 & 8,8 & 1,30 & ns \\
\hline Pati (kg/ekor/hari) & 6,6 & 6,5 & 6,6 & 0,64 & ns \\
\hline \multicolumn{6}{|c|}{ Transit silase jagung } \\
\hline TMRT (jam) & 50,8 & 52,0 & 51,2 & 2,60 & ns \\
\hline Tk1 (jam) & 26,8 & 27,7 & 27,0 & 1,90 & ns \\
\hline Tk2 (jam) & 12,4 & 13,0 & 13,5 & 2,20 & ns \\
\hline tt (jam) & 11,7 & 11,3 & 10,7 & 0,50 & ns \\
\hline
\end{tabular}

Keterangan :

R : $20 \%$ konsentrat, $\mathrm{S}: 35$ konsentrat dan $\mathrm{T}: 50$ konsentrat

TMRT : Lama tinggal partikel pakan dalam saluran pencernaan total

Tk1 : lama tinggal partikel pakan dalam retikulo-rumen,

Tk2 : TMRT - Tk1 - tt, waktu komunisi partikel dan transit partikel dalam cecum-colon proksimal dan caillet

tt : Waktu pertama kali marka muncul dalam feces

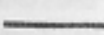

Konser

TMRT

Tk1 (ja:

Tk2 (ja

tt (jam)

$\operatorname{kp}\left(\% / \sigma_{j}\right)$

Keterang

R

TMRT

Tk1

The

tt

Transit p:

Tra

kg/ekor/hari untuk R, S dan T). Hal ini sesuai dengan hasil yang dilaporkan oleh Weiss et al. (1989); Ceceva et al. (1990) dan Colucci et al. (1990) bahwa aras konsentrat dalam ransum < $70 \%$ tidak mempengaruhi secara nyata lama tinggal pakan dalam sahuran pencernaan terutama bila kualitas pakan basalnya baik seperti silase jagung. Walaupun Gasa et al. (1991) dan Colucci et al. (1982) melaporkan bahwa peningkatan aras konsentrat dalam ransum meningkatkan TMRT dan Tk1.

\section{Transit konsentrat}

TMRT konsentrat berbeda tidak nyata diantara perlakuan, masing-masing 39,$0 ; 37,4$ dan 36,7 jam untuk $R$, $S$ dan $T$. Hal ini didukung $T k 1$ dan $T k 2$ antara perlakuan juga berbeda tidak nyata, masing-masing 21,$6 ; 20,8$ ; 19,9 jam dan 5,$8 ; 5,6 ; 6,4$ jam untuk $R$, $S$ dan $T$. Perbedaan aras konsentrat serat tidak berpengaruh nyata pada transit partikel konsentrat disebabkan lama tinggal dałam rumen dipengaruhi oleh ukuran partikel pakan yang merupakan hasil mastikasi dan degradasi pakan oleh mikrobia dimana pada ransum perlakuan tidak jauh berbeda, hal ini didukung Tk2 yang merupakan waktu yang dibutuhkan untuk memperkecil partikel pakan dan marka muncul pertama dalam feces (tt) berbeda tidak nyata diantara perlakuan. Kandungan serat (NDF) dan pati serta konsumsinya antara ketiga periakuan tidak berbeda menyebabkan struktur isi rumen relatif sama, sehingga waktu yang dibutuhkan untuk mencapai ukuran partikel tertentu untuk mengalir keluar rumen di antara ketiga ransum tidak berbeda. Hal ini sesuai pendapat Mambrini (1991) bahwa konsentrat yang ukuran partikelnya relatif kecil sedikit dipengaruhi oleh faktor-faktor yang mempengaruhi transit partikel seperti level intake dibanding hijauan. berdasarke yang dika TMRT k $(\mathbb{P}<0,01)$ dapat dije dan $T k 2$ silase jagu jam). Perb jagung dar merubah pada sila: konsentrat kecil, sehi lebih cepat Hasil yang (1991) bal saluran $p$ hijauan dar konsentrat Variasi ind parameter tertinggi $\mathrm{d} a$ silase jagun Lam hijauan dar 
Tabel 4. Pengaruh aras konsentrat terhadap transit konsentrat dalam saluran pencernaan

\begin{tabular}{lccccc}
\hline \multicolumn{1}{c}{ Item } & $20(\mathrm{~T})$ & $35(\mathrm{~S})$ & $50(\mathrm{~T})$ & SE & $\begin{array}{c}\text { Analisis } \\
\text { statistik }\end{array}$ \\
\hline Konsentrat & & & & & \\
TMRT (jam) & 39,0 & 37,4 & 36,7 & 2,10 & ns \\
Tk1 (jam) & 21,6 & 20,8 & 19,9 & 1,80 & ns \\
TK2 (jam) & 5,8 & 5,7 & 6,4 & 1,30 & ns \\
tt (jam) & 11,7 & 11,0 & 10,3 & 1,10 & ns \\
kP $(\% /$ jam $)$ & 4,63 & 4,81 & 5,03 & 0,8 & ns \\
\hline
\end{tabular}

\section{Keterangan :}

R : $: 20 \%$ konsentrat, $\mathrm{S}: 35$ konsentrat dan $\mathrm{T}: 50$ konsentrat

TMRT : Lama tinggal partikel pakan dalam saluran pencernasn total

Tk1 : lama tinggal partikel pakan dalam retikulo-rumen,

Tk2 : TMRT - Tk1 - tt, waltu komunisi partikel dan transit partikel dalam cecum-colon proksimal dan caillet

tt : Waktu pertama kali marka muncul dalam feces

Transit partikel ransum

Transit partikel ransum yang dihitung berdasarkan proporsi hijauan dan konsentrat yang dikconsumsi disajikan pada Tabel 5 . TMRT konsenirat lebih pendek 13,7 jam $(\mathrm{P}<0,01)$ dibanding silase jagung, perbedaan ini dapat dijelaskan oleh adanya perbedaan TK1 dan T 22 konsentrat lebih singkat dibanding silase jagung (masing-masing 6,4 jam dan 7,1 jam). Perbedaan TMRT, Tk1 dan Tk1 silase jagung dan konsentrat disebabkan waktu untuk merubah partikel besar menjadi partikel kecil pada silase jagung lebih lama dibanding konsentrat yang ukuran partikelnya relatif lebih kecil, sehingga aliran partikel keluar rumen lebih cepat konsentrat dibanding silase jagung. Hasil yang sama juga dilaporkan Mambrini (1991) bahwa transit pertikel konsentrat di saluran pencernaan lebih cepat dibanding hijauan dan selisihnya bervariasi menurut tipe konsentrat dan jenis hijauan yang digunakan. Variasi individu ternak juga cukup tinggi pada parameter transit, perbedaan TMRT antara tertinggi dan terendah mencapi 15,4 jam untuk silase jagung dan 11,8 jam untuk konsentrat.

Lama tinggal ransum yang terdiri dari hijauan dan konsentrat di saluran pencernaan lebih tinggi $(\mathbf{P}<0,05)$ pada ransum $\mathbf{R}$ dibanding $\mathrm{T}$ dan antara ransum $\mathrm{S}$ dan $\mathrm{T}$ berbeda tidak nyata (Tabel 5). Perbedaan TMRT ini disebabkan oleh perbedaan Tkl ransum $R$ lebih lama dibanding $T$ dan $k p$ ransum $R$ lebih panjang dibanding ransum $\mathrm{T}$ (masing-masing 48,4 vs 43,9 jam dan 3,61 vs $2,28 \% / j a m$ ). Data sebelumnya (Tabel 3 dan 4) menunjukkan bahwa lama tinggal masing-masing hijauan dan konsentrat di saluran pencernaan berbeda tidak nyata, tetapi berbeda nyata pada ransum total, hal ini menunjukkan adanya efek asosiasi antara hijauan dan konsentrat. Adanya efek asosiasi antara hijauan dan konsentrat terhadap intake dan kecernaan termasuk transit partikel dalam saluran pencernaan telah dilaporkan Journet et al. (1988). Colucci ef al. (1982) juga melaporkan bahwa kenaikan aras konsentrat dari $18 \%$ menjadi $67 \%$ meningkatkan lama tinggal pakan di total saluran pencernaan dari $24-44$ jam pada sapi perah kering dengan pakan terbatas, pengaruh negatif kenaikan aras konsentrat dalam ransum disebabkan oleh modifikasi struktur isi rumen, penurunan $\mathrm{pH}$, motrisitas dan penurunan produksi saliva (Poncet, 1991). 
Tabel 5. Pengaruh aras konsentrat terhadap transit ransum dalam saluran pencernaan

\begin{tabular}{lccccc}
\hline \multicolumn{1}{c}{ Item } & $20(\mathrm{~T})$ & $35(\mathrm{~S})$ & $50(\mathrm{~T})$ & SE & $\begin{array}{c}\text { Analisis } \\
\text { statistik }\end{array}$ \\
\hline $\begin{array}{l}\text { Ransum } \\
\text { TMRT (jam) }\end{array}$ & $48,4^{\mathrm{a}}$ & $46,9^{\mathrm{a}}$ & $43,9^{\mathrm{b}}$ & 2,20 & $*$ \\
Tk1 (jam) & $27,7^{\mathrm{a}}$ & $25,3^{\mathrm{a}}$ & $23,5^{\mathrm{b}}$ & 1,70 & $*$ \\
Tk2 (jam) & 11,0 & 10,4 & 10,0 & 1,80 & ns \\
tt (jam) & 11,7 & 11,2 & 10,5 & 1,00 & ns \\
kp (\%/jam) & $3,61^{\mathrm{a}}$ & $3,95^{\mathrm{a}}$ & $2,28^{\mathrm{b}}$ & 0,23 & $* *$ \\
\hline
\end{tabular}

Keterangan :

R : $20 \%$ konsentrat, $\mathrm{S}: 35$ konsentrat dan $\mathrm{T}: 50$ konsentrat

TMRT : Lama tinggal partikel pakan dalam saluran pencernaan total

Tk1 : lama tinggal partikel pakan dalam retikulo-rumen,

Tk2 : TMRT - Tk1 - tt, waktu komunisi partikel dan transit partikel dalam cecum-colon proksimal dan caillet

tt : Waktu pertama kali marka muncul dalam feces

Dinamik cairan dalam rumen.

Hasil estimasi dinamik cairan dalam rumen yang terdiri dari pergantain cairan (k)), volume rumen (V) dan flux cairan keluar rumen disajikan pada Tabel 6. Berdasarkan analisis statistik menunjukkan bahwa $\mathrm{kl}, \mathrm{V}$ dan flux antara ternak yang mendapatkan ransum R, S dan T berbeda tidak nyata. Rerata kd adalah $11,27 \% / \mathrm{jam}, \mathrm{V}=93,31$ dan flux cairan keluar rumen 251,7//ekor/hari. Hasil penelitian diatas yang berbeda tidak nyata dimungkinkan ransum $\mathrm{R}, \mathrm{S}$ dan $\mathrm{T}$ mempunyai kandungan NDF dan pati dan bentuk ransum relatif tidak berbeda, menyebabkan saliva yang diproduksi oleh ternak tidak berbeda. Mambrini (1991) menunjukkan bahwa cairan rumen mewakili

Tabel 6. Pengaruh aras konsentrat terhadap dinamik cairan dalam rumen

\begin{tabular}{lccccc}
\hline Item & $20(\mathrm{~T})$ & $35(\mathrm{~S})$ & $50(\mathrm{~T})$ & SE & $\begin{array}{c}\text { Analisis } \\
\text { statistik }\end{array}$ \\
\hline \multicolumn{1}{c}{ Ransum } & & & & & \\
kl (\%/jam) & 11,3 & 11,4 & 11,1 & 1,00 & ns \\
Volume (I) & 94 & 91 & 95 & 13,0 & ns \\
Flux (/hari) & 256 & 247 & 252 & 31,0 & ns \\
\hline
\end{tabular}

Keterangan :

R : $20 \%$ konsentrat, $\mathrm{S}: 35$ konsentrat dan $\mathrm{T}: 50$ konsentrat

ld : pergantian cairan dalam rumen, $\mathrm{V}$ : volume rumen

Ceceva, $\mathbf{M}$.

L. I

Rum

Sstee

Leve 
$\pm 85 \%$ dari isi rumen, $70-90 \%$ cairan tersebut berasal dari saliva dan hanya $10-30 \%$ berasal dari air pakan, air minum dan pergantain air melalui dinding rumen. Colucci et al. (1989); Weiss et al. (1989); Ceceva et al. (1990) ; Klusmeyer et at. (1991) juga melaporkan bahwa pergantian cairan dalam rumen tidak berbeda nyata atau hanya cendenung berbeda bila aras konsentrat dalam ransum tidak melebihi $65 \%$.

\section{Kesimpulan}

Berdasarkan hasil penelitian dapat disimpulkan sebagai berikut :

1. Peningkatan aras konsentrat dalam ransum basal yang berkualitas baik (silase jagung) tidak memberikan perbedaan nyata baik lama tinggal silase jagung dan konsentrat di dalam retikulorumen, cecum-colon proksimal maupun total saluran pencernaan serta dinamik cairan rumen.

2. Lama tinggal ransum dalam rumen dan total saluran pencernaan menurun dengan peningkatan aras konsentrat menunjukkan adanya asosiasi antara silase jagung dengan konsentrat.

\section{Ucapan Terima Kasih}

Penulis mengucapkan terima kasih kepada INRA Station de Recherches sur La Vache Laitieres Saint Gilles France terutama dan kepada monsieur $R$. Verite dan J. L. Peyraud yang telah memberi kesempatan dan arahan serta menanamkan disiplin pada penulis mulai dari pembuatan proposal sampai pelaksanaan penelitian.

\section{Dafar Pustaka}

Ceceva, M. J., N. R. Merchen, R. C. Gay, and L. L. Berger. 1990. Composition of Ruminal Bacteria Harvested from Ssteers as Influenced by Dietary Energy Level, Feeding Frequency and Isolation
Technique. J. Dairy Sci. 73, 24702479.

Colucci, P. E., L. E. Cahse and P. J. Van Soest. 1982. Feed Intake, Apparent Diet Digestibility and Rate of Particulate Passage in Dairy Cattle. J.Dairy. Sci. 65, 1445-1456.

Colucci, P. E., G. K. MCleod, W. L. Grovum, L. W. Cahill, and W. R. MCmillan. 1989. Comparative Digestion in Sheep and Cattle Fed Different Forage to Concentrate Ratios at High and Low Intakes. J. Dairy. Sci. 72, (7) 17751785.

Colucci, P. E., G. K. MCleod, W. L. Grovum, L. W. Cahill, and W. R. MCmillan. 1990. Digesta Kinetics in Sheep and Cattle Fed diets With Different Forage to Concentrate Ratios at High and Low Intakes. J. Dairy. Sci., 73,2143-2156.

Coulon, J. P., A. Hoden, P. Faverdin and M. Joumet. 1989. Dairy Cows. R. Jarrige (Ed.). In: Ruminant Nutrition Recommendation and Feed Tables. Institut National de la Recherche Agronomique. Paris.

Ellis, W. C., M. J. Wylie, and J. H Matis. 1988.

Dietary Digestive Interactions

Determining the Feeding Value of Forages and Roughages. In : Neimann Sorensen, A., Tribe, D.E. (Eds), World Animal Science. B. Disciplinary Approach, 177-228.

Faverdin, F., R. Baumont, and K. L. Ingvarsten. 1995. Control and Prediction of Feed Intake in Ruminants. Journet, M., E. Grenet, M.H. Farce, M. Theriez, C. Demarquilly (Eds), In : Recent Developments in the Nutrition of Herbivores, 95-114.

Gasa, J., K. Holtenius, J. D. Sutton, M. S. Dhanoa, and D. J. Napper. 1991. Rumen Fill and Digesta Kinetics in Lactating Friesian Cow Given Two Level of Concentrate with Two Types 
of Grass silages ad. Lib. Br. J. Nutr. 66, 381-398.

Goetsch, A. L., and F. N. Owens. 1985. Effects of Sampling Site on Passage Rate Estimate in Heifers Fed Alfafa or High Concentrate Diet. J. Dairy Sci. 68, 914-922.

Harrison, D. G., D. E. Beever, D. J. Thomson, and D. F. Osbourn. 1975. Manipulation of Rumen Fermentation in Sheep by Increasing the Rate of Outflow of Water from the Rumen. J. Agric. Sci. Camb., 85, 93-101.

Hoover, W. H., and J. G. Welch. 1985. Effects of Particle Size and Forage Composition on Functional Specific Gravity. J. dairy Sci. 68, 1181-1188.

Joumet. 1988. Optimisation des Ration. R. Jarrige (Ed.). In: Alimentation des Bovins Ovins \& Caprins. Institut National de la Recherche Agronomique. Paris.

Katho, K., F. Sato, A. Yamazaki, Y. Sasaki, and T. Tsuda. 1988. Passage of Digestible Particles of Various Specific Gravities in Sheep and Goats. Br. $J$. Nutr. 60, 683-687.

Klusmeyer, T. H., G. L. Lynch, J. N. Clark, and D. R. Nelson. 1991. Effect of Calcium Salts of Fatty Cids and Proportion of Forage in the Diet on Ruminal Fermentation and Nutrien Flow to Duodenum of Cows. J. Dairy. Sci. 74, 2220-2032.

Malawar, S. J., and D. W. Powell. 1967. An Improve Turbidimetric Analysis of Polyethylene Glycol Utilizing and Emulsifier. Gastroent. 53 (2), 250-256.

Mambrini, M. 1991. Etude du Temps de Sejour des Residues Alimentaires Dans le Tube Digestif des Vaches Laitieres : Aspects Methodologiques et Facteurs de Variation. These de l'Universite de Rennes I.

Martz, F. A., and R. Belyea. 1986. Symposium : Forage Utilization by Lactating Cow. Role of Particle Size and Forage Quality in Digestion and Passage by Cattle and Sheep. J. Dairy Sci. 69, 1996-2008.

Reid, C. S. W. 1986. Digestive Physiology, the Challenges Today and Tomorrow. Milligan L. P., Grovum, W .L., Dobson, A. (Eds), In : Control of Digestion and Metabolism in Ruminants. 540-557.

Rode, L. M., and L. D. Satter. 1988. Effect of Amount and Length of Alfafa Hay in Diets Containing Barley or Com on Site of Digestion and Rumen Microbial Protein Synthesis in Dairy Cows. Can J. Anim. Sci. 68, 445-454.

Rode, L. M., D. C. Wearly, and L. D. Satter. 1985. Effect of Forage Amount and Particle Size in Diets of Lactating Dairy Cows on Site of Digestion and Microbial Protein Synthesis. Can J. Anim. Sci. 65, 101-111.

SAS Institut Inc. 1987. SAS/STAT Guide for Personel Computer, Version 6 Edit. SAS Institut Inc., Cary, NC. 1028 p.

Weiss, W. P., and W. L. Shockey. 1991. Value of Orchard Grass and Alfalfa Silages Fed with Varying Amounts of Concentrates to Dairy Cows. J. Dairy Sci. 74, 1933-1943.

Zorrilla-Rios, J., J. D. Garza, and F. N. Owens. 1991. Fate of Drinking Water in Ruminants : Simultaneous Comparison of Two Methods to Estimate Ruminal Evasion. Anim. Sci. Res. Rep. 167-169. penampile meningke: tahun, der dalam $\mathrm{ra}$ penambah pakan das berat bade pemberian sehari, pa: analisis $\mathrm{v}$ : dianalisis bahwa pe harian (31 $60,75 \mathrm{~g} / \mathrm{k}_{\mathrm{i}}$ 17,$81 ; 16$, 15,$62 ; 11$ 6.395,66; berpengan memperlih

(Ka

${ }^{1}$ Fakultas $\mathrm{F}$ 